\title{
Susceptibility of Coronavirus Disease-19 in Pediatric Population
}

\author{
Riska Habriel Ruslie ${ }^{1 *}$, Darmadi Darmadi², Gontar Alamsyah Siregar ${ }^{2}$ \\ ${ }^{1}$ Department of Child Health, Faculty of Medicine, Universitas Prima Indonesia, Medan, Indonesia; ${ }^{2}$ Department of Internal \\ Medicine, Faculty of Medicine, Universitas Sumatera Utara, Haji Adam Malik General Hospital, Medan, Indonesia
}

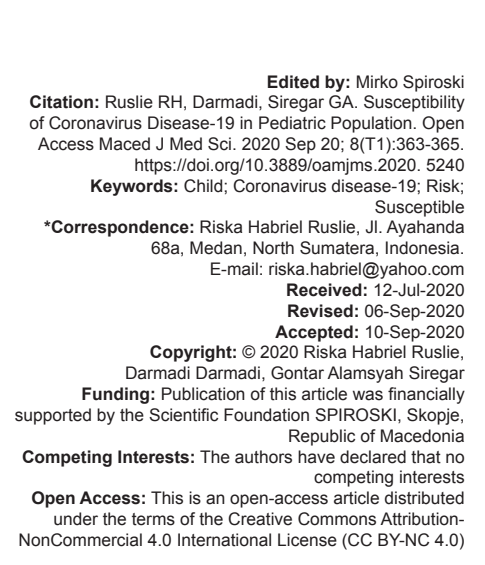

\section{Abstract}

Since the end of 2019 until present, coronavirus (CoV) disease (COVID)-2019 has spread globally and caused a pandemic. The disease is caused by severe acute respiratory syndrome-2 (SARS-CoV-2). The disease is showed to be less affecting pediatric population. The proportion children suffering from COVID-19 is only around $2 \%$ of total cases with only $0.08 \%$ mortality rate. Several hypotheses have been proposed regarding this condition. Children are supposed to be less exposed to patients with COVID-19, have lesser amount of angiotensin converting enzyme 2 , have different immune response compared to adults, and have faster tissue recovery ability. All of them decrease the possibility of SARS-CoV-2 infection in pediatric population.

\section{Introduction}

In December 2019, new cases of pneumonia were reported in China. The epicenter of the disease was suspected in Huanan seafood market in Wuhan, Hubei Province [1], [2], [3]. The disease was caused by severe acute respiratory syndrome-2 (SARSCoV-2) and was later named as coronavirus (CoV) disease-2019 (COVID-19) [4]. COVID-19 spread rapidly around the globe and was declared as a pandemic by World Health Organization in March 11, 2020 [5]. The most common mode of transmission is through respiratory droplet. There was no evidence regarding vertical transmission from mother to child [6], [7], [8]. However, antibody toward SARS-CoV-2 was detected in newborns from mothers with COVID-19. Therefore, separation of newborns from their COVID-19 infected mothers is advised [7].

The epidemiological data regarding COVID-19 in children is not certain. It is due to lack of COVID-19 screening in pediatric population from asymptomatic disease course in most of this population [7], [8]. Children are also less affected by COVID-19 compared to adults. The prevalence rates of pediatric COVID-19 in China and Italy are $2 \%$ and $1.2 \%$, respectively [7], [9]. Even more, neonatal case is very rare. Male children are affected more than female ones [7]. Most pediatric cases of COVID-19 are asymptomatic to mild with reported mortality of $0.08 \%$ [7], [8], [9]. Several hypotheses are raised regarding the low susceptibility and mortality of COVID-19 in children. We will discuss about the hypotheses in this review.

\section{Pathogenesis of COVID-19}

$\mathrm{CoV}$ is an enveloped single-stranded positivesense ribonucleic acid (RNA) virus. It consists of alpha and beta genera where SARS-CoV-2 belongs to beta genera [6], [10]. At first, COVID-19 is thought to be transmitted from snakes. Latterly, studies showed that mammals are the possible carriers for the disease [6]. After entering human's body mainly through respiratory tract, virus' spike glycoprotein (a surface glycoprotein) binds angiotensin converting enzyme (ACE) 2. This process is followed by fusion of virus with cell membrane. Virus' RNA will integrate into host deoxyribonucleic acid. Host cell will then synthesize virus' proteins. New viruses are assembled and ready to infect other cells, causing death in previous host cell [6], [11], [12]. The symptoms of COVID-19 are fever, cough, fatigue, dyspnea, and diarrhea. Some upper respiratory tract symptoms may present in COVID-19 patients such as 
rhinorrhea, sneezing, and sore throat [6], [8], [9]. Realtime polymerase chain reaction from nasopharyngeal swab is considered as the gold standard for diagnosing COVID-19 [6], [7].

\section{"Lack of Exposure" Hypothesis}

Human to human transmission occurs due to mutation of SARS-CoV-2 genome from its wild ancestor [13]. Compared to adults, children tend to have fewer outdoor activities. This gives this population a forced social and physical distancing even before the COVID-19 pandemic [14]. A study stated that the probability of children in contact with infected patients is $1.3 \%$ compared to $3.5 \%$ in adults [15]. This clearly lower the susceptibility of COVID-19 compared to adult population.

\section{"Lack of Receptor" Hypothesis}

Children have less mature and functional ACE2. As ACE2 is important viral receptor, this condition is suggested to be protective factor for COVID-19 in children [7], [9], [14]. This is supported by a fact that viral load in pediatric population is not different from that in adult ones. However, a study in rats showed that the quantity of ACE2 is decreased in older rats compared to younger ones [7].

\section{“Different Immune Response” Hypothesis}

Children have more active innate immune system which allows a more rapid clearance of the virus [14], [15], healthier respiratory tract due to less exposure of cigarette smoke and air pollutant, and less comorbidity [14]. Innate immune system consists of neutrophils, monocytes, macrophages, and dendritic cells. In newborns, both innate and adaptive immune system functions are not perfect. As time goes by, innate immune system getting more active before decreasing into adult state while adaptive immune system gradually active. As age advances, the immune system becomes impaired due to remodeling and declining processes [16]. The amount of antigen presenting cells in respiratory tract of children is similar with those in adults. In contrast, the amount of macrophages and monocytes is higher in children [17]. The presence of thymus in children causes an increase in lymphocyte maturation and number. Even though the lymphocyte function is impaired, its amount may improve host immunity toward viral infections [16].

Innate immune system eliminates viruses through production of interferons by dendritic cells and monocytes [15]. Those cells recognize viral nucleic acids through toll-like receptors. Interferons will activate natural killer cells and adaptive immune response to further helping in viral elimination. Natural killer cells lyse virus-infected cells and prevent viral replication and spreading [16], [18]. Innate immune system combined with $\mathrm{T}$ and $\mathrm{B}$ cell responses are important for viral clearance [15].

In the other hand, recurrent infection of the upper respiratory tract in children is postulated to induce a condition called trained immunity [15]. The concept of trained immunity was introduced in 2011. According to the concept, bacterial infection induces cross-protection against other pathogens [9]. In this condition, monocytes and other myeloid cells undergo epigenetic changes which increase their capability to eliminate antigens including SARS-CoV-2 [15].

Less comorbidity in children prevents immune over reactivity and further cytokine storm [15]. Adaptive immune system in children is also not well-developed, giving less cytokine production, and lower probability of cytokine storm [17]. That's why children usually only show asymptomatic to mild COVID-19 manifestations. Similar reason underlies the low mortality rate of children with COVID-19 [15].

\section{“Faster Recovery” Hypothesis}

In children, tissue repair process is better compared to adults. Tissue repair is influenced by efferocytosis (non-inflammatory cell death) and M2 repair program which is related with monocytes/ macrophages. These processes are mediated by resolvins. Resolvins are expressed more during childhood. However, infants aged $<1$ year are at higher risk of COVID-19. It is hypothesized that this population has immature immune response and absence trained immunity [15].

\section{Conclusion}

Several hypotheses have been proposed regarding the low susceptibility of COVID-19 in pediatric population. Children are less exposed to patients with COVID-19. They also have lower expression of ACE2 and the SARS-CoV-2 receptor. Immune response in pediatric population is also different from adult, giving 
protective effect toward COVID-19. Lastly, pediatric population possesses an ability of faster tissue recovery.

\section{References}

1. Ge H, Wang X, Yuan X, Xiao G, Wang C, Deng T, et al. The epidemiology and clinical information about COVID-19. Eur J Clin Microbiol Infect Dis. 2020;39(6):1011-9. https://doi. org/10.1007/s10096-020-03874-z

PMid:32291542

2. Bi Q, Wu Y, Mei S, Ye C, Zou X, Zhang Z, et al. Epidemiology and transmission of COVID-19 in 391 cases and 1286 of their close contacts in Shenzhen, China: A retrospective cohort study. Lancet Infect Dis. 2020;20(8):911-9. https://doi.org/10.1016/ s1473-3099(20)30287-5

PMid:32353347

3. Musa S. Hepatic and gastrointestinal involvement in coronavirus disease 2019 (COVID-19): What do we know till now? Arab J Gastroenterol. 2020;21(1):3-8. https://doi.org/10.1016/j. ajg.2020.03.002

PMid:32253172

4. Fan Z, Chen L, Li J, Cheng X, Yang J, Tian C, et al. Clinical features of COVID-19-related liver functional abnormality. Clin Gastroenterol Hepatol. 2020;18(7):1561-6. https://doi. org/10.1016/j.cgh.2020.04.002

PMid:32283325

5. Cai Q, Huang D, Yu H, Zhu Z, Xia Z, Su Y, et al. COVID-19: Abnormal liver function tests. J Hepatol. 2020;73(3):566-74. https://doi.org/10.1016/j.jhep.2020.04.006 PMid:32298767

6. Rothan HA, Byrareddy SN. The epidemiology and pathogenesis of cronavirus disease (COVID-19) outbreak. J Autoimmun. 2020;109:102433. https://doi.org/10.1016/j.jaut.2020.102433 PMid:32113704

7. Liguoro I, Pilotto C, Bonanni M, Ferrari ME, Pusiol A, Nocerino A, et al. SARS-COV-2 infection in children and newborns: A systematic review. Eur J Pediatr. 2020;179(7):1029-46. https:// doi.org/10.1007/s00431-020-03684-7

\section{PMid:32424745}

8. Jeng M. Coronavirus disease 2019 in children: Current status. J Chin Med Assoc. 2020;83(6):527-33. https://doi.org/10.1097/ jcma.0000000000000323

PMid:32502117

9. Lyu J, Miao T, Dong J, Cao R, Li Y, Chen Q. Reflection on lower rates of COVID-19 in children: Does childhood immunizations offer unexpected protection? Med Hypotheses. 2020;143:109842. https://doi.org/10.1016/j.mehy.2020.109842 PMid:32425304

10. Cheung KS, Hung IF, Chan PP, Lung K, Tso E, Liu R, et al. Gastrointestinal manifestations of SARS-CoV-2 infection and virus load in fecal samples from the Hong Kong cohort and systematic review and meta-analysis. Gastroenterology. 2020;159(1):81-95. https://doi.org/10.1053/j.gastro.2020.03.065 PMid:32251668

11. Zhang C, Shi L, Wang F. Liver injury in COVID-19: Management and challenges. Lancet Gastroenterol Hepatol. 2020;5:428-30. https://doi.org/10.1016/s2468-1253(20)30057-1

PMid:32145190

12. Xudong $\mathrm{X}$, Junzhu $\mathrm{C}$, Xingxiang $\mathrm{W}$, Furong $\mathrm{Z}$, Yanrong $\mathrm{L}$. Age and gender-related difference of ACE2 expression in rat lung. Life Sci. 2006;78(19):2166-71. https://doi.org/10.1016/j. Ifs.2005.09.038

PMid:16303146

13. Zhang $X$. Epidemiology of Covid-19. N Engl J Med. 2020;382(19);1869-70. https://doi.org/10.1056/nejmc200515 PMid:32220200

14. Lee $\mathrm{P}, \mathrm{Hu} \mathrm{Y}$, Chen $\mathrm{P}$, Huang $\mathrm{Y}$, Hsueh $\mathrm{P}$. Are children less susceptible to COVID-19? J Microbiol Immunol Infect. 2020;53(3):371-2. https://doi.org/10.1016/j.jmii.2020.02.011 PMid:32147409

15. Fischer A. Resistance of children to Covid-19. How? Mucosal Immunol. 2020;13:563-5. https://doi.org/10.1038/ s41385-020-0303-9

16. Simon AK, Hollande GA, McMichael A. Evolution of the immune system in humans from infancy to old age. Proc Bio Soc. 2015;282(1821):20143085. https://doi.org/10.1098/ rspb.2014.3085

PMid:26702035

17. Georgountzou A, Papadopoulos NG. Postnatal innate immune development: From birth to adulthood. Front Immunol. 2017;8:957. https://doi.org/10.3389/fimmu.2017.00957 PMid:28848557

18. Prendergast AJ, Klenerman P, Goulder PJR. The impact of differential antiviral immunity in children and adults. Nat Rev Immunol. 2012;12(9):636-48. https://doi.org/10.1038/nri3277 PMid:22918466 